(C) Elsevier/INRA

Original article

\title{
The effect of alternative mating designs and selection strategies on adult multiple ovulation and embryo transfer (MOET) nucleus breeding schemes in dairy cattle
}

\author{
J Ruane \\ AFRC Institute of Animal Physiology and Genetics Research, Roslin, \\ Midlothian, EH25 9PS*; \\ Institute of Animal Genetics, University of Edinburgh, Kings Buildings, \\ West Mains Road, Edinburgh, EH9 $3 J N$, Scotland, UK
}

(Received 17 April 1990; accepted 3 December 1990)

\begin{abstract}
Summary - The impact of alternative mating designs and selection strategies on rates of response and inbreeding in closed adult multiple ovulation and embryo transfer (MOET) nucleus breeding schemes in dairy cattle was investigated by Monte Carlo simulation. Results were compared with those from schemes using hierarchical mating designs and with one male chosen at random from each selected male full sib group. The use of more than one male from each selected sibship reduced inbreeding rates by $24-34 \%$ because more sires were used. With one male chosen from each selected sibship, factorial mating designs increased response rates by up to $13 \%$ because the number of sibships, and hence the number of male candidates, was increased. Finally, factorial sibship schemes, which employed both of these strategies, increased response rates by $5-14 \%$ and, with one exception, reduced inbreeding rates by $14-30 \%$.
\end{abstract}

breeding programmes / embryo transfer / dairy cattle / genetic gain

Résumé - Effets du système de croisement et de la stratégie de sélection chez les bovins laitiers sur les schémas utilisant l'ovulation multiple et le transfert d'embryons. L'impact de différents systèmes de croisement et de stratégies de sélection sur les taux de réponse et sur l'augmentation de la consanguinité a été étudié par simulation, dans le cas d'un noyau de sélection de bovins laitiers, conduit en population fermée et exploitant l'ovulation mulliple et le transfert d'embryons chez les adultes. Les résultats ont été comparés à ceux obtenus dans les schémas utilisant un plan hiérarchique d'accouplement et $\grave{a}$ ceux obtenus dans le cas où un seul mâle est choisi au hasard dans un groupe sélectionné de pleins-frères. L'utilisation de plusieurs mâles dans une même fratrie sélectionnée diminue le taux de consanguinité de 24 à $34 \%$, car un plus grand nombre de reproducteurs sont utilisés. Avec un seul mâle choisi par fratrie sélectionnée, les plans de croisement factoriels peuvent augmenter le taux de réponse jusqu'à $13 \%$ car le nombre de fratries, et donc le nombre de candidats à la sélection est accru. Finalement, un plan factoriel sur les

* Address for correspondence and reprints 
fratries qui réunit les deux stratégies permet d'accroître la réponse de 5 à $14 \%$ et, à une exception près, de réduire le taux de consanguinité de 14 à $30 \%$.

programmes de sélection / transfert d'embryons / bovins laitiers / progrès génétique

\section{INTRODUCTION}

Previous studies (eg Ruane and Thompson, 1989) have shown that adult MOET nucleus schemes as described by Nicholas and Smith (1983) are likely to yield substantially lower rates of genetic progress and far higher rates of inbreeding than originally predicted.

However, the schemes proposed by Nicholas and Smith (1983), (which will be referred to as hierarchical schemes), were of a specific nature. A hierarchical mating design was used with each sire mated at random to a constant number of dams and each dam mated to only 1 sire. Each mating produced a fixed number of daughters and a single son for selection. The number of sons eligible for selection per dam was restricted to one in order to reduce inbreeding by preventing the automatic coselection of male full sibs. This would occur since males are evaluated on pedigree information only and so all full sibs have the same estimated breeding value (EBV).

The aim of this study was to examine the implications of using alternative mating designs and selection strategies in adult MOET nucleus schemes. Three alternatives were investigated. The first was the use of more than 1 male from each selected sibship. In this situation the number of sires used was increased without reducing the sibship selection pressure. Nicholas and Smith (1983) suggested that this strategy would reduce inbreeding but made no attempt to quantify the possible benefits.

The second alternative examined was the use of factorial mating designs, where each dam is mated to more than 1 sire. As pointed out by Woolliams (1989), in this situation the number of sire $\times$ dam mating combinations is increased compared to the hierarchical design. With one son per full sib group eligible for selection, he predicted that higher rates of response would be achieved, due to the increased number of male candidates, without increasing inbreeding.

Finally, the benefits possible from combining the use of more than one male from each selected sibship with factorial mating designs were investigated.

\section{MATERIALS AND METHODS}

\section{Description of simulation}

Ruane and Thompson (1991) have described the Monte Carlo simulation in detail. A brief summary is given here. For each scheme a closed nucleus herd of high genetic merit was established, followed by 6 discrete generations of single trait selection within the nucleus herd.

The nucleus was established by intense selection of nucleus founder animals from 100 male candidates and 6400 female candidates at generation 0 (the base generation). The true breeding values (TBVs) of these candidates were taken at random from a normal distribution with a variance of 0.25 while their EBVs 
were generated so that the correlation between TBVs and EBVs was 0.88 and 0.65 for males and females respectively. Because the permanent and temporary environmental variances of the trait of interest were assumed to equal 0.25 and 0.5 , the phenotypic variance was 1.0 and the heritability and repeatability in the base generation were 0.25 and 0.5 respectively.

Candidates were ranked according to EBVs, selected and then mated at random using MOET. An infinitesimal genetic model (Bulmer, 1980) was assumed. The TBVs of offspring in each generation were derived by:

$$
g_{i}=g_{s} / 2+g_{D} / 2+m_{i}
$$

where $g_{i}, g_{s}$ and $g_{D}$ represent respectively the TBVs of an offspring, of its sire and of its dam. The term representing the effect of Mendelian sampling, $m_{i}$, was taken at random from a normal distribution with a mean of 0 and a variance equal to

$$
\left(1 / 2-\left(F_{s}+F_{D}\right) / 4\right) \sigma_{g o}^{2}
$$

where $F_{s}$ and $F_{D}$ are the inbreeding coefficients of the sire and dam and $\sigma_{g o}^{2}$ represents genetic variance in the base generation (ie 0.25). Animals selected in the base generation were assumed to be unrelated.

Animals of each generation were eligible for selection only once, after the first lactation record was completed. In practice, this would give a generation interval of $\approx 4 \mathrm{yr}$. Selected females were kept in the nucleus for 2 further lactations to provide additional records for breeding value estimation. The genetic correlation between lactations was assumed to be one. The natural calves of nucleus females were ignored and only offspring bred by MOET were eligible for selection in the next generation. Unselected females had no further lactations.

To optimise resources in a MOET nucleus scheme, selection and embryo transfer should occur annually. The simulation model dictates that animals are selected and MOET used once per generation (ie every $4 \mathrm{yr}$ ). However, because selection is carried out in discrete annual cycles, the results calculated (rates of response etc) are the same as if the model had included annual cycles of selection. Thus when describing the selection of animals etc, it is understood that in a practical scheme this would be carried out annually. Assuming a $50 \%$ sex ratio and a $50 \%$ survival rate of embryos to selection, the simulated schemes would require 256-1024 embryo transfers each year and so are similar in size to those currently under consideration or in operation (Colleau and Mocquot, 1989).

Because the selected trait was sex limited, only females had phenotypes. For the $k^{\text {th }}$ record of the $i^{\text {th }}$ individual measured in the $j^{\text {th }}$ herd-year, these were produced by

$$
Y_{i j k}=g_{i}+p_{i}+b_{j}+t_{i j k}
$$

where $Y, g, p, b$ and $t$ represent the full lactation record, TBV, permanent environmental effect, herd-year effect and temporary environmental effect respectively. Each first lactation female was randomly assigned to one of 4 herds.

For the 6 generations of selection within the nucleus, an individual animal model, based on the "indirect approach" method of Schaeffer and Kennedy (1986), was used to calculate best linear unbiased predictions (BLUP) of breeding values. After generation 0 , only records on cows born in the nucleus were used for evaluation, 
so that information on nucleus founders was ignored. Omitting this information, which would be of limited value because the nucleus founders are both intensely and accurately selected, also simplified the breeding value estimation procedures.

\section{Calculation of simulation results}

\section{Response to selection}

The response to selection expected per generation is

$$
\Delta G=\left(r_{M} i_{M}+r_{F} i_{F}\right) \sigma_{g} / 2
$$

where $\Delta G$ is the response to selection; $\sigma_{g}$ is the genetic standard deviation; $r_{M}$ and $r_{F}$ represent the accuracies of selection for males and females and $i_{M}$ and $i_{F}$ represent the selection intensities for males and females. These last 5 parameters are the components of response.

Genetic response and each of the 5 components of response were calculated from the simulation for each generation and were then averaged over all replicates. To summarise the results for each scheme, simulated results from generations 2-6 (inclusive) were averaged within each replicate and then over all replicates. Generation 1 results were excluded because the scheme was not yet considered to be fully established due to the lack of nucleus ancestral information.

\section{Inbreeding}

Inbreeding coefficients were calculated using the relationship matrix and inbreeding rates were calculated for each generation using the formula

$$
\Delta F=\left(F_{t}-F_{t-1}\right) /\left(1-F_{t-1}\right)
$$

where $\Delta F$ is the rate of inbreeding per generation and $F_{t}$ and $F_{t-1}$ are the average inbreeding coefficients of animals born at generations $t$ and $t-1$ respectively.

\section{Description of simulated schemes}

\section{Hierarchical mating designs and the use of full brothers from selected sibships (hierarchical sibship schemes)}

Since the EBV of each male was identical to that of his full brothers, allowing more than one male per sibsinip to be eligible for selection had no effect on male selection pressures, provided the number of selected sibships was constant. To keep the selection pressure constant (at 1 in 4 or 1 in 8 respectively), the number of sires used increased in proportion to the number of males per sibship eligible for selection. Eight breeding schemes were examined, and these are described in table I.

The number of males used per selected sibship was set to $1,2,3$ or 4 while the number of females per sibship was 4 in all cases. Thirty-two dams and 4 or 8 sibships were selected. With 1,2 and 4 males per sibship each sire was mated to an equal number of dams. With 3 males per sibship, some sires, chosen at random, 
Table I. Description of schemes using hierarchical mating designs and permitting the use of full brothers from selected sibships (hierarchical sibship schemes). Thirty-two dams were selected in each scheme.

No of male sibships selected

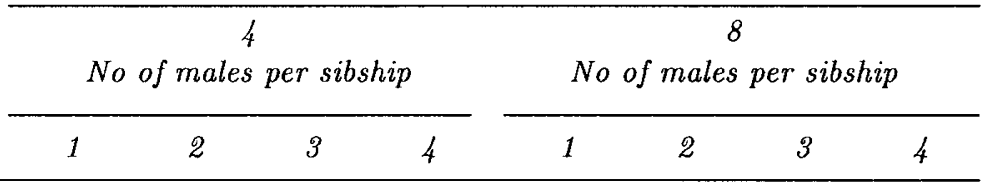

\begin{tabular}{lcccccccc}
\hline $\begin{array}{l}\text { No of sires } \\
\text { selected }\end{array}$ & 4 & 8 & 12 & 16 & 8 & 16 & 24 & 32 \\
$\begin{array}{l}\text { No of dams } \\
\text { mated per sire }\end{array}$ & 8 & 4 & $2.67^{1}$ & 2 & 4 & 2 & $1.33^{2}$ & 1 \\
$\begin{array}{l}\text { No of sons } \\
\text { per sire }\end{array}$ & 8 & 8 & $8^{1}$ & 8 & 4 & 4 & $4^{2}$ & 4 \\
$\begin{array}{l}\text { Total No of } \\
\text { male candidates }\end{array}$ & 32 & 64 & 96 & 128 & 32 & 64 & 96 & 128 \\
$\begin{array}{l}\text { No of daughters } \\
\text { per dam }\end{array}$ & 4 & 4 & 4 & 4 & 4 & 4 & 4 & 4 \\
$\begin{array}{l}\text { No of daughters } \\
\text { per sire }\end{array}$ & 32 & 16 & $10.67^{1}$ & 8 & 16 & 8 & $5.33^{2}$ & 4 \\
$\begin{array}{l}\text { Proportion of } \\
\text { males selected }\end{array}$ & $4 / 32$ & $8 / 64$ & $12 / 96$ & $16 / 128$ & $8 / 32$ & $16 / 64$ & $24 / 96$ & $32 / 128$ \\
$\begin{array}{l}\text { Proportion } \\
\text { of females } \\
\text { selected }\end{array}$ & $32 / 128$ & $32 / 128$ & $32 / 128$ & $32 / 128$ & $32 / 128$ & $32 / 128$ & $32 / 128$ & $32 / 128$ \\
\hline
\end{tabular}

${ }^{1}$ Eight sires were mated to 3 dams and 4 sires to 2 dams. ${ }^{2}$ Sixteen sires were mated to 1 dam and 8 sires to 2 dams.

were mated to an additional dam. The use of 1 male per sibship represents the hierarchical schemes described by Nicholas and Smith (1983).

To keep the selection pressure on founder males constant for the hierarchical and hierarchical sibship schemes, the number of founder sires selected to set up the nucleus in the base generation was assumed to equal the number of male sibships selected within the nucleus in subsequent generations. Thirty-two dams were selected in all generations and each scheme was replicated 350 times.

\section{Factorial mating designs (factorial schemes)}

The technique of MOET involves flushing embryos from donors at repeated time intervals, usually 6-8 wk. Because a different sire can be used at each flush, this opens up the possibility of utilising factorial mating designs. Compared to hierarchical mating designs, this means that each dam is mated to more than one 
sire and that each sire is mated to an increased number of dams. The total number of different mating pairs increases, while the family size per mating decreases.

The number of sires mated to each dam was set to $1,2,3$ or 4 while 4 or 8 sires and 32 dams were selected. Each simulation was replicated 350 times. The schemes are described in table II.

Table II. Description of schemes using factorial mating designs (factorial schemes). Thirty-two dams were selected in each scheme.

\begin{tabular}{|c|c|c|c|c|c|c|c|c|}
\hline & \multicolumn{8}{|c|}{ No of sires selected } \\
\hline & \multicolumn{4}{|c|}{$\begin{array}{c}4 \\
\text { No of sires mated } \\
\text { per dam }\end{array}$} & \multicolumn{4}{|c|}{$\begin{array}{c}8 \\
\text { No of sires mated } \\
\text { per dam }\end{array}$} \\
\hline & 1 & 2 & 3 & 4 & 1 & 2 & 3 & 4 \\
\hline $\begin{array}{l}\text { No of dams mated } \\
\text { per sire }\end{array}$ & 8 & 16 & 24 & 32 & 4 & 8 & 12 & 16 \\
\hline $\begin{array}{l}\text { No of sons } \\
\text { per dam }\end{array}$ & 1 & 2 & 3 & 4 & 1 & 2 & 3 & 4 \\
\hline $\begin{array}{l}\text { No of sons } \\
\text { per sire }\end{array}$ & 8 & 16 & 24 & 32 & 4 & 8 & 12 & 16 \\
\hline $\begin{array}{l}\text { Total No of } \\
\text { male candidates }\end{array}$ & 32 & 64 & 96 & 128 & 32 & 64 & 96 & 128 \\
\hline $\begin{array}{l}\text { No of daughters } \\
\text { per dam }\end{array}$ & 4 & 4 & 4 & 4 & 4 & 4 & 4 & 4 \\
\hline $\begin{array}{l}\text { No of daughters } \\
\text { per sire }\end{array}$ & 32 & 32 & 32 & 32 & 16 & 16 & 16 & 16 \\
\hline $\begin{array}{l}\text { Proportion of } \\
\text { males selected }\end{array}$ & $4 / 32$ & $4 / 64$ & $4 / 96$ & $4 / 128$ & $8 / 32$ & $8 / 64$ & $8 / 96$ & $8 / 128$ \\
\hline $\begin{array}{l}\text { Proportion of } \\
\text { females } \\
\text { selected }\end{array}$ & $32 / 128$ & $32 / 128$ & $32 / 128$ & $32 / 128$ & $32 / 128$ & $32 / 128$ & $32 / 128$ & $32 / 128$ \\
\hline
\end{tabular}

One sire per dam represents the hierarchical schemes. As assumed by Nicholas and Smith (1983), only 1 male per full sibship was eligible for selection. With 1, 2, 3 and 4 sires per dam, the number of matings, ie the number of sibships, was 32 , 64, 96 and 128 respectively. In all cases, the number of daughters per dam was 4 . Factorial designs were used in each generation, including the base generation.

By replacing hierarchical with factorial mating designs, the population structure and the genetic relationships among individuals were changed. Maternal as well as paternal half sibs were generated. In addition, the number of full sisters was reduced, each being replaced by 1 maternal and 1 paternal half sib. For example, with 8 sires and 32 dams selected, each male had 4 full sisters and 12 paternal half sisters in the hierarchical scheme. By comparison, when each dam was mated to 
2 sires, each male had 2 full sisters with 14 paternal and 2 maternal half sisters. Furthermore, with 1 son per mating the number of males was increased so that each individual had more half brothers.

The factorial designs were arranged so that the number of different combinations of sires mated to each dam was maximised, thus making the population as heterogeneous as possible. For a given number of sires selected $(n)$ and a given number of sires mated to each dam $(r)$, the total number of different combinations of sires per dam possible can be derived by

$$
\left(\begin{array}{l}
n \\
r
\end{array}\right)=\frac{n(n-1)(n-2) \ldots(n-r+1)}{1.2 .3 \ldots(r-1) \cdot r}
$$

With $n=4$ there are 4,6, 4 and 1 different sire combinations for $r=1,2,3$ and 4 respectively. With $n=8$ there are $8,28,56$ and 70 combinations for $r=1,2,3$ and 4 . Because the number of dams, and hence the number of different combinations possible, was 32 , all but 2 of the designs had at least 1 complete set of sire combinations. For the remaining 2 designs ( 8 sires selected and each dam mated to 3 or 4 sires) cyclic (John et al, 1972) and randomised incomplete block designs (Cochran and Cox, 1957) were used respectively.

\section{Factorial mating designs and the use of full brothers from selected sibships (factorial sibship schemes)}

In the factorial schemes just outlined, only one male per sibship was considered for selection. An alternative proposal would be to use more than one male per sibship while selecting a constant number of sibships. With this strategy, the selection pressure would be unchanged and, since a greater number of males would be selected, inbreeding should be reduced.

With fixed resources the number of males eligible for selection per sibship is limited when factorial mating designs are used, since the increased number of matings is achieved by reducing the number of offspring per mating. Let us assume that each dam is flushed 4 times with 1 son and 1 daughter surviving to selection from each flush. If the dam is mated to the same sire at all 4 flushes (ie hierarchical mating) then 4 daughters and, depending on whether restrictions are imposed, up to 4 sons are eligible for selection. By comparison, if a different sire is used at each flush then each sibship contains just 1 daughter and 1 son. Consequently, it is only when each dam is mated to 2 sires ( 2 flushes per sire), resulting in sibships of 2 males and 2 females, that factorial designs can be combined with the use of male sibs.

Four or 8 sibships and 16,32 or 64 dams were selected. Schemes were replicated 600,350 and 170 times respectively with 16,32 and 64 dams selected and are described in table III. In addition, to allow the effects of sibship selection and factorial designs to be compared independently, schemes using the same sire and dam numbers as above were also simulated but with 2 males and 4 females per sibship and a hierarchical mating design (hierarchical sibship schemes) and with 1 male and 2 females per sibship and with 2 sires mated to each dam in a factorial design (factorial schemes). These schemes also extend the hierarchical sibship and factorial schemes described previously, which were limited to 32 dams. 
Table III. Description of schemes using factorial mating designs and permitting the use of full brothers from selected sibships (factorial sibship schemes). Each dam was mated to 2 sires and there were 2 sons and 2 daughters per sibship.

\begin{tabular}{|c|c|c|c|c|c|c|}
\hline & \multicolumn{6}{|c|}{ No of male sibships selected } \\
\hline & \multicolumn{3}{|c|}{$\begin{array}{c}4 \\
\text { No of dams selected }\end{array}$} & \multicolumn{3}{|c|}{$\begin{array}{c}8 \\
\text { No of dams selected }\end{array}$} \\
\hline & 16 & 32 & 64 & 16 & 32 & 64 \\
\hline $\begin{array}{l}\text { No of sires } \\
\text { selected }\end{array}$ & 8 & 8 & 8 & 16 & 16 & 16 \\
\hline $\begin{array}{l}\text { No of dams } \\
\text { mated per sire }\end{array}$ & 4 & 8 & 16 & 2 & 4 & 8 \\
\hline $\begin{array}{l}\text { No of sons } \\
\text { per dam }\end{array}$ & 4 & 4 & 4 & 4 & 4 & 4 \\
\hline $\begin{array}{l}\text { No of sons } \\
\text { per sire }\end{array}$ & 8 & 16 & 32 & 4 & 8 & 16 \\
\hline $\begin{array}{l}\text { Total No of } \\
\text { male candidates }\end{array}$ & 64 & 128 & 256 & 64 & 128 & 256 \\
\hline $\begin{array}{l}\text { No of daughiters } \\
\text { per dam }\end{array}$ & 4 & 4 & 4 & 4 & 4 & 4 \\
\hline $\begin{array}{l}\text { No of daughters } \\
\text { per sire }\end{array}$ & 8 & 16 & 32 & 4 & 8 & 16 \\
\hline $\begin{array}{l}\text { Proportion of } \\
\text { males selected }\end{array}$ & $8 / 64$ & $8 / 128$ & $8 / 256$ & $16 / 64$ & $16 / 128$ & $16 / 256$ \\
\hline $\begin{array}{l}\text { Proportion of } \\
\text { females selected }\end{array}$ & $16 / 64$ & $32 / 128$ & $64 / 256$ & $16 / 64$ & $32 / 128$ & $64 / 256$ \\
\hline
\end{tabular}

In the factorial sibship schemes with 4 sibships selected, 4 sires were selected in the base generation and mated in a hierarchical design (for the sake of simplicity) to the 16, 32 or 64 base generation founder dams. Each mating resulted in 2 sons and 4 daughters. Because the number of matings and sibships was halved, male selection intensities were lower in generation one than in subsequent generations. For generations 1 to 6,8 sires (ie 4 sibships of 2 males each) were selected. With 32 and 64 dams, all 28 pairwise combinations of the 8 sires were possible and so were used. With 16 dams all combinations were not possible, so a cyclic design (John et al, 1972) was used.

With 8 sibships selected, 8 sires were selected in the base generation and mated in a hierarchical design to the 16, 32 or 64 founder dams. For all other generations, 16 sires (ie 8 sibships of 2 males each) were selected and mated to 32 or 64 dams using a cyclic design (John et al, 1972) or to 16 dams with a partially balanced incomplete block design (Cochran and Cox, 1957). 


\section{RESULTS}

\section{Hierarchical sibship schemes}

The response to selection, the components of response and the rates of inbreeding averaged over generations 2 to 6 are shown in table IV. The results show that using full brothers from selected sibships reduced inbreeding rates substantially without adversely affecting response.

Rates of inbreeding were highest with 1 son per dam eligible for selection (hierarchical schemes). When full brothers were used, inbreeding rates were reduced by $26-34 \%$ and by $24-31 \%$ with 4 and 8 sibships selected respectively.

Table IV. Genetic response (in phenotypic standard deviation units), the five components of response and inbreeding rates per generation in hierarchical sibship schemes. Results were averaged over generations 2-6 (inclusive). Thirty-two dams were selected in each scheme ${ }^{1}$.

\begin{tabular}{|c|c|c|c|c|c|c|c|c|}
\hline & \multicolumn{8}{|c|}{ No of male sibships selected } \\
\hline & \multicolumn{4}{|c|}{$\begin{array}{l}4 \\
\text { No of males per sibship }\end{array}$} & \multicolumn{4}{|c|}{$\begin{array}{c}8 \\
\text { No of males per sibship }\end{array}$} \\
\hline & 1 & 2 & 3 & 4 & 1 & 2 & 3 & 4 \\
\hline$\sigma_{g}$ & 0.420 & 0.429 & 0.429 & 0.431 & 0.437 & 0.442 & 0.442 & 0.443 \\
\hline$r_{M}$ & 0.401 & 0.395 & 0.380 & 0.375 & 0.408 & 0.391 & 0.384 & 0.378 \\
\hline$i_{M}$ & 1.456 & 1.547 & 1.568 & 1.582 & 1.215 & 1.243 & 1.244 & 1.250 \\
\hline$r_{F}$ & 0.535 & 0.536 & 0.527 & 0.527 & 0.546 & 0.541 & 0.536 & 0.535 \\
\hline$i_{F}$ & 1.199 & 1.234 & 1.240 & 1.249 & 1.233 & 1.250 & 1.251 & 1.256 \\
\hline$\Delta G$ & 0.260 & 0.277 & 0.268 & 0.270 & 0.261 & 0.258 & 0.254 & 0.254 \\
\hline$\Delta F$ & 7.77 & 5.71 & 5.25 & 5.13 & 4.60 & 3.50 & 3.19 & 3.42 \\
\hline
\end{tabular}

${ }^{1}$ Standard errors ranged from $0.001-0.005$ for response and the components of response and from $0.03-0.08$ for inbreeding rates.

Sibship selection produced distinct changes in each of the 5 response components. The genetic standard deviation was increased by selecting more sires and by the subsequent reduction in inbreeding. The subdivision of the population into smaller groups and the breakup of large discrete sire family units affected the accuracies and intensities of selection. By using more than 1 male from each selected sibship, accuracies of selection for both sexes were reduced because half sib records were replaced by an equal number from first cousins.

For example, with 8 sibships selected, each male candidate had 4 full sisters and 12 half sisters when 1 male per sibship was eligible per selection. However, when 4 males were used from each selected sibship, each male had 4 full sisters and 12 female first cousins but no half sisters. Thus, as more sires were selected, the accuracies of selection declined. 
The subdivision of the population into smaller units reduced the impact of family structure on the male and female intensities of selection (Hill, 1976). In addition, by selecting more sires the effect of finite numbers on male selection intensities (Burrows, 1972) was diminished. The resulting increases in selection intensities were considerably greater when 4 sibships were selected. For this reason, response with sibship selection increased when 4 sibships were selected but was reduced when 8 sibships were selected.

When 4 or 8 sibships were selected, genetic gain was higher with 2 males per sibship eligible for selection than with 3 or 4 males. This was due to the fact that as the number of males per sibship increased, the decline in the accuracies of selection was greater than the rise in selection intensities and the genetic standard deviation.

Selection responses over generations 1-6 are shown in table V. Because of higher inbreeding rates, response was considerably more variable with one son per dam eligible for selection. The decline in response from generations 2-6 was also greater. By comparison, the decline in response with 4 sons per dam was quite small.

Table V. Response to selection for generations 1-6 in hierarchical sibship schemes. $\Delta G$ is the average response from generations $2-6$. Results are presented \pm standard deviation of response. Thirty-two dams were selected in each scheme. The standard error is the standard deviation divided by 18.7 .

\begin{tabular}{|c|c|c|c|c|c|c|c|c|}
\hline \multirow{3}{*}{$\begin{array}{l}\text { Generation } \\
\text { No }\end{array}$} & \multicolumn{8}{|c|}{ No of male sibships selected } \\
\hline & \multicolumn{4}{|c|}{$\begin{array}{l}4 \\
\text { No of males per sibship }\end{array}$} & \multicolumn{4}{|c|}{$\begin{array}{c}8 \\
\text { No of males per sibship }\end{array}$} \\
\hline & & 2 & 3 & 4 & 1 & 2 & & 3 \\
\hline 1 & $\begin{array}{r}0.226 \\
\pm 0.135\end{array}$ & $\begin{array}{rr}6 & 0.234 \\
5 & \pm 0.116\end{array}$ & $\begin{array}{r}0.226 \\
\pm 0.100\end{array}$ & $\begin{array}{r}0.224 \\
\pm 0.104\end{array}$ & $\begin{array}{r}0.210 \\
\pm 0.098\end{array}$ & $\begin{array}{r}0.205 \\
\pm 0.085\end{array}$ & $\begin{array}{r}0.208 \\
\pm 0.080\end{array}$ & $\begin{array}{lr}8 & 0.207 \\
0 & \pm 0.080\end{array}$ \\
\hline 2 & $\begin{array}{r}0.283 \\
\pm 0.139\end{array}$ & $\begin{array}{lr}3 & 0.292 \\
9 & \pm 0.118\end{array}$ & $\begin{array}{r}0.272 \\
\pm 0.097\end{array}$ & $\begin{array}{r}0.270 \\
\pm 0.102\end{array}$ & $\begin{array}{r}0.273 \\
\pm 0.106\end{array}$ & $\begin{array}{r}0.251 \\
\pm 0.093\end{array}$ & $\begin{array}{r}0.254 \\
\pm 0.083\end{array}$ & $\begin{array}{lr}4 & 0.250 \\
3 & \pm 0.080\end{array}$ \\
\hline 3 & $\begin{array}{r}0.277 \\
\pm 0.146\end{array}$ & $\begin{array}{rr}7 & 0.286 \\
6 & \pm 0.113\end{array}$ & $\begin{array}{r}0.278 \\
\pm 0.104\end{array}$ & $\begin{array}{r}0.279 \\
\pm 0.104\end{array}$ & $\begin{array}{r}0.271 \\
\pm 0.108\end{array}$ & $\begin{array}{r}0.272 \\
\pm 0.091\end{array}$ & $\begin{array}{r}0.262 \\
\pm 0.093\end{array}$ & $\begin{array}{rr}2 & 0.259 \\
3 & \pm 0.082\end{array}$ \\
\hline 4 & $\begin{array}{r}0.262 \\
\pm 0.133\end{array}$ & $\begin{array}{lr}2 & 0.284 \\
3 & \pm 0.121\end{array}$ & $\begin{array}{r}0.270 \\
\pm 0.103\end{array}$ & $\begin{array}{r}0.277 \\
\pm 0.097\end{array}$ & $\begin{array}{r}0.263 \\
\pm 0.102\end{array}$ & $\begin{array}{r}0.263 \\
\pm 0.090\end{array}$ & $\begin{array}{r}0.261 \\
\pm 0.085\end{array}$ & $\begin{array}{lr}1 & 0.252 \\
5 & \pm 0.084\end{array}$ \\
\hline 5 & $\begin{array}{r}0.255 \\
\pm 0.118\end{array}$ & $\begin{array}{rr}5 & 0.268 \\
8 & \pm 0.114\end{array}$ & $\begin{array}{r}0.265 \\
\pm 0.110\end{array}$ & $\begin{array}{r}0.262 \\
\pm 0.118\end{array}$ & $\begin{array}{r}0.251 \\
\pm 0.100\end{array}$ & $\begin{array}{r}0.251 \\
\pm 0.084\end{array}$ & $\begin{array}{r}0.255 \\
\pm 0.085\end{array}$ & $\begin{array}{lr}5 & 0.254 \\
5 & \pm 0.084\end{array}$ \\
\hline 6 & $\begin{array}{r}0.226 \\
\pm 0.123\end{array}$ & $\begin{array}{rr}6 & 0.256 \\
3 & \pm 0.107\end{array}$ & $\begin{array}{r}0.254 \\
\pm 0.102\end{array}$ & $\begin{array}{r}0.260 \\
\pm 0.104\end{array}$ & $\begin{array}{r}0.246 \\
\pm 0.106\end{array}$ & $\begin{array}{r}0.255 \\
\pm 0.091\end{array}$ & $\begin{array}{r}0.241 \\
\pm 0.082\end{array}$ & $\begin{array}{rr}1 & 0.254 \\
2 & \pm 0.085\end{array}$ \\
\hline$\Delta G$ & $\begin{array}{r}0.260 \\
\pm 0.060\end{array}$ & $\begin{array}{lr}0 & 0.277 \\
0 & \pm 0.049\end{array}$ & $\begin{array}{r}0.268 \\
\pm 0.050\end{array}$ & $\begin{array}{r}0.270 \\
\pm 0.047\end{array}$ & $\begin{array}{r}0.261 \\
\pm 0.050\end{array}$ & $\begin{array}{r}0.258 \\
\pm 0.040\end{array}$ & $\begin{array}{r}0.254 \\
\pm 0.043\end{array}$ & $\begin{array}{rr}4 & 0.254 \\
3 & \pm 0.040\end{array}$ \\
\hline
\end{tabular}




\section{Factorial schemes}

Selection response, the components of response and inbreeding rates averaged over generations 2-6 are shown in table VI. As the number of sires mated to each dam increased, the number of sibships and male candidates increased, since one male per sibship was eligible for selection. As a consequence, genetic gain increased by up to $13 \%$ as the number of sires mated to each dam was raised from 1 to 4 . Woolliams (1989), using deterministic methods, predicted increases of a similar magnitude for comparable schemes, although the predicted responses were $>50 \%$ higher than simulated results because the effects of selection and inbreeding on genetic variances were ignored.

Table VI. The genetic response, the 5 components of response and the rates of inbreeding with factorial schemes. Results were averaged over generations 2-6 (inclusive). Thirty-two dams were selected in each scheme ${ }^{1}$.

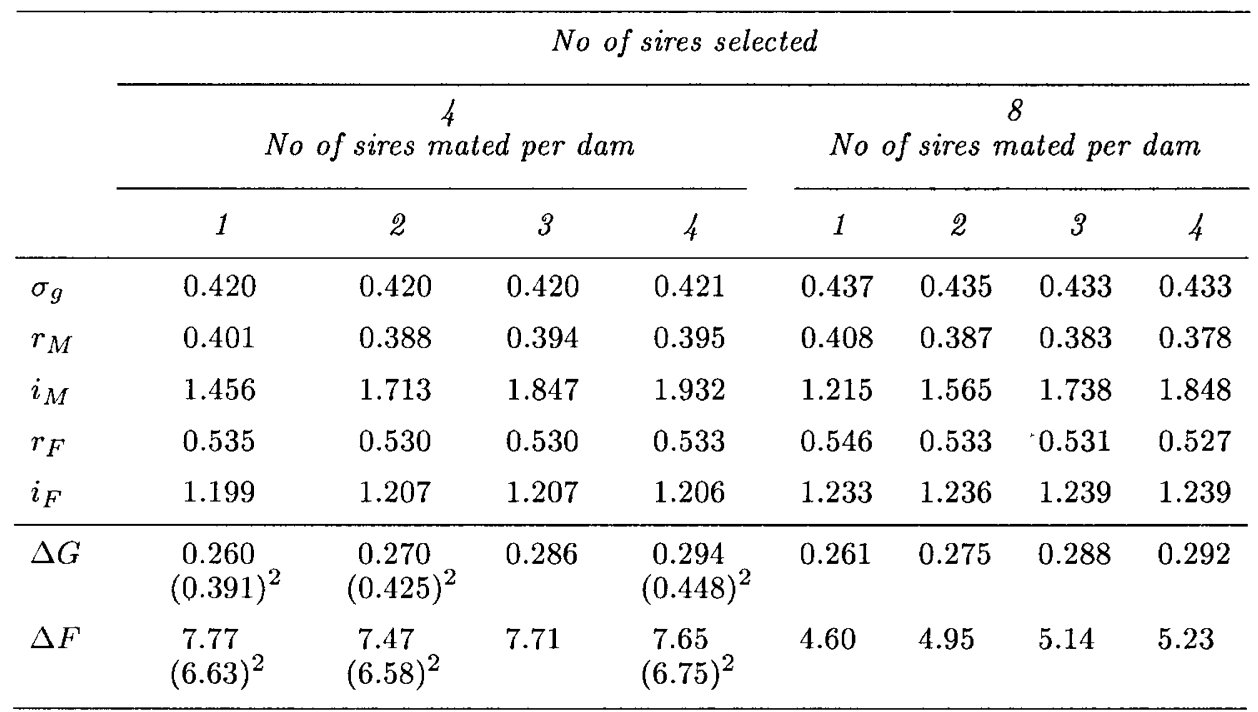

1 Standard errors ranged from 0.001-0.006 for response and the components of response and from $0.05-0.08$ for inbreeding rates. ${ }^{2}$ Predictions from Woolliams (1989), with 4 sires and 36 dams selected.

The increased number of males candidates resulted in substantially higher male section intensities. By comparison, the other 4 components of response were relatively constant. The accuracies of selection declined slightly due to the reduction of between sire variances with increasing selection pressure (Bulmer, 1971).

With 4 sires selected, inbreeding rates were slightly lower when factorial mating designs were used. Inbreeding rates with factorial and hierarchical mating designs are relatively similar because the increased probability of coselecting half sibs with factorial designs is balanced by the reduced probability of coselecting full sibs. Woolliams (1989) also found little change in inbreeding for comparable schemes. 
With 8 sires selected the picture was slightly different. Inbreeding rates increased (up to 14\%) as more sires were mated to each dam. With hierarchical mating designs, the number of sons per sire eligible for selection was restricted so that selected males were bred by at least 2 sires. With factorial mating designs, this restriction was removed and consequently individual sires were able to have a greater number of sons selected, thus increasing the inbreeding rates.

Selection responses achieved over generations one to six are shown in table VII Almost without exception, the response at each generation increased steadily as the number of sires mated to each dam was increased. Because the factorial schemes had little impact on inbreeding, the standard deviations of response were virtually unaffected by the mating design.

Table VII. Response to selection for generations 1-6 with factorial schemes. $\Delta G$ is the average response from generations 2-6. Results are presented \pm standard deviation of response. Thirty-two dams were selected in each scheme. The standard error is the standard deviation divided by 18.7 .

No of sires selected

\begin{tabular}{|c|c|c|c|c|c|c|c|c|}
\hline \multirow[b]{2}{*}{$\begin{array}{l}\text { Generation } \\
\text { No }\end{array}$} & \multicolumn{4}{|c|}{ No of sires mated per dam } & \multicolumn{4}{|c|}{$\begin{array}{c}8 \\
\text { No of sires mated per dam }\end{array}$} \\
\hline & 1 & 2 & 3 & 4 & 1 & 2 & 3 & 4 \\
\hline 1 & $\begin{array}{r}0.226 \\
\pm 0.135\end{array}$ & $\begin{array}{r}0.239 \\
\pm 0.129\end{array}$ & $\begin{array}{r}0.233 \\
\pm 0.126\end{array}$ & $\begin{array}{r}0.250 \\
\pm 0.130\end{array}$ & $\begin{array}{r}0.210 \\
\pm 0.098\end{array}$ & $\begin{array}{r}0.224 \\
\pm 0.104\end{array}$ & $\begin{array}{r}0.223 \\
\pm 0.100\end{array}$ & $\begin{array}{r}0.234 \\
\pm 0.103\end{array}$ \\
\hline 2 & $\begin{array}{r}0.283 \\
\pm 0.139\end{array}$ & $\begin{array}{r}0.285 \\
\pm 0.141\end{array}$ & $\begin{array}{r}0.304 \\
\pm 0.145\end{array}$ & $\begin{array}{r}0.310 \\
\pm 0.138\end{array}$ & $\begin{array}{r}0.273 \\
\pm 0.106\end{array}$ & $\begin{array}{r}0.291 \\
\pm 0.109\end{array}$ & $\begin{array}{r}0.296 \\
\pm 0.111\end{array}$ & $\begin{array}{r}0.303 \\
\pm 0.115\end{array}$ \\
\hline 3 & $\begin{array}{r}0.277 \\
\pm 0.146\end{array}$ & $\begin{array}{r}0.285 \\
\pm 0.132\end{array}$ & $\begin{array}{r}0.296 \\
\pm 0.136\end{array}$ & $\begin{array}{r}0.313 \\
\pm 0.141\end{array}$ & $\begin{array}{r}0.271 \\
\pm 0.108\end{array}$ & $\begin{array}{r}0.277 \\
\pm 0.119\end{array}$ & $\begin{array}{r}0.301 \\
\pm 0.120\end{array}$ & $\begin{array}{r}0.309 \\
\pm 0.115\end{array}$ \\
\hline 4 & $\begin{array}{r}0.262 \\
\pm 0.133\end{array}$ & $\begin{array}{r}0.275 \\
\pm 0.137\end{array}$ & $\begin{array}{r}0.302 \\
\pm 0.131\end{array}$ & $\begin{array}{r}0.307 \\
\pm 0.136\end{array}$ & $\begin{array}{r}0.263 \\
\pm 0.102\end{array}$ & $\begin{array}{r}0.269 \\
\pm 0.104\end{array}$ & $\begin{array}{r}0.291 \\
\pm 0.110\end{array}$ & $\begin{array}{r}0.294 \\
\pm 0.120\end{array}$ \\
\hline 5 & $\begin{array}{r}0.255 \\
\pm 0.118\end{array}$ & $\begin{array}{r}0.262 \\
\pm 0.134\end{array}$ & $\begin{array}{r}0.267 \\
\pm 0.137\end{array}$ & $\begin{array}{r}0.276 \\
\pm 0.129\end{array}$ & $\begin{array}{r}0.251 \\
\pm 0.100\end{array}$ & $\begin{array}{r}0.276 \\
\pm 0.107\end{array}$ & $\begin{array}{r}0.283 \\
\pm 0.111\end{array}$ & $\begin{array}{r}0.285 \\
\pm 0.104\end{array}$ \\
\hline 6 & $\begin{array}{r}0.226 \\
\pm 0.123\end{array}$ & $\begin{array}{r}0.245 \\
\pm 0.122\end{array}$ & $\begin{array}{r}0.259 \\
\pm 0.126\end{array}$ & $\begin{array}{r}0.264 \\
\pm 0.128\end{array}$ & $\begin{array}{r}0.246 \\
\pm 0.106\end{array}$ & $\begin{array}{r}0.262 \\
\pm 0.102\end{array}$ & $\begin{array}{r}0.271 \\
\pm 0.110\end{array}$ & $\begin{array}{r}0.270 \\
\pm 0.106\end{array}$ \\
\hline$\Delta G$ & $\begin{array}{r}0.260 \\
\pm 0.060\end{array}$ & $\begin{array}{r}0.270 \\
\pm 0.062\end{array}$ & $\begin{array}{r}0.286 \\
\pm 0.062\end{array}$ & $\begin{array}{r}0.294 \\
\pm 0.059\end{array}$ & $\begin{array}{r}0.261 \\
\pm 0.050\end{array}$ & $\begin{array}{r}0.275 \\
\pm 0.051\end{array}$ & $\begin{array}{r}0.288 \\
\pm 0.053\end{array}$ & $\begin{array}{r}0.292 \\
\pm 0.052\end{array}$ \\
\hline
\end{tabular}

\section{Factorial sibship schemes}

Selection response, the components of response and inbreeding rates averaged over generations 2-6 are shown in table VIII. Compared to hierarchical schemes, 
Table VIII. The genetic response, the 5 components of response and the rates of inbreeding with factorial sibship schemes. Each dam was mated to 2 sires and 2 males and 2 females per sibship were eligible for selection. Results were averaged over generations 2-6 (inclusive). The figures in brackets represent percentage changes compared to the standard (Nicholas and Smith, 1983) design, ie hierarchical mating design with one son per dam eligible for selection ${ }^{1}$.

No of male sibships selected

\begin{tabular}{cccccccc}
\multicolumn{3}{c}{} & \multicolumn{3}{c}{ No of dams selected } & & \multicolumn{3}{c}{ No of dams selected } \\
\cline { 7 - 8 } \cline { 6 - 8 } & 16 & 32 & 64 & & 16 & 32 & 64 \\
\hline$\sigma_{g}$ & 0.426 & 0.430 & 0.429 & & 0.437 & 0.442 & 0.441 \\
& $(0.9 \%)^{2}$ & $(2.6 \%)$ & $(1.8 \%)$ & & $(-1.2 \%)$ & $(1.1 \%)$ & $(2.2 \%)$ \\
$r_{M}$ & 0.346 & 0.384 & 0.413 & & 0.339 & 0.366 & 0.393 \\
& $(-6.2 \%)$ & $(-4.4 \%)$ & $(-7.3 \%)$ & & $(-10.5 \%)$ & $(-10.4 \%)$ & $(-9.3 \%)$ \\
$i_{M}$ & 1.554 & 1.823 & 2.055 & & 1.244 & 1.605 & 1.905 \\
& $(34.5 \%)$ & $(25.2 \%)$ & $(22.7 \%)$ & & $(63.5 \%)$ & $(32.1 \%)$ & $(22.7 \%)$ \\
$r_{F}$ & 0.504 & 0.528 & 0.549 & & 0.493 & 0.525 & 0.544 \\
& $(-2.6 \%)$ & $(-1.4 \%)$ & $(-2.1 \%)$ & & $(-7.4 \%)$ & $(-4.0 \%)$ & $(-2.3 \%)$ \\
$i_{F}$ & 1.234 & 1.235 & 1.238 & & 1.278 & 1.253 & 1.256 \\
& $(3.6 \%)$ & $(3.0 \%)$ & $(3.4 \%)$ & & $(4.5 \%)$ & $(1.6 \%)$ & $(1.6 \%)$ \\
\hline$\Delta G$ & 0.250 & 0.296 & 0.326 & & 0.231 & 0.275 & 0.314 \\
& $(10.9 \%)$ & $(13.6 \%)$ & $(8.5 \%)$ & & $(9.7 \%)$ & $(5.5 \%)$ & $(6.2 \%)$ \\
$\Delta F$ & 6.79 & 5.77 & 5.44 & & 4.81 & 3.80 & 3.33 \\
& $(-14.4 \%)$ & $(-25.8 \%)$ & $(-26.0 \%)$ & & $(13.4 \%)$ & $(-17.4 \%)$ & $(-30.4 \%)$ \\
\hline
\end{tabular}

1 Standard errors ranged from 0.001-0.009 for response and the components of response and from 0.04-0.08 for inbreeding rates. ${ }^{2}\left(\left(\sigma_{g}\right.\right.$ factorial sibship $/ \sigma_{g}$ hierarchical $\left.)-1\right) \times$ $100=0.9$.

responses were $5-14 \%$ higher and, apart from one scheme, rates of inbreeding were 14-30\% lower.

The higher responses achieved were due mainly to substantial increases in male selection intensities (23-64\%) resulting from both the use of more sires, thus reducing the effects of finite numbers (Burrows, 1972) and population structure (Hill, 1976) and, more importantly, the increased numbers of male candidates. Because full brothers were used, some (up to all) half sib records were replaced with information on first cousins. Consequently, the accuracies of selection were reduced by $1-10 \%$.

Selection responses over generations 1-6 are shown in table IX. As the schemes increased in size greater selection responses were achieved and, due to larger effective population sizes the standard deviation of response decreased. Compared to hierarchical schemes, the highest responses were generally achieved slightly later 
Table IX. Response to selection for generations 1-6 with factorial sibship schemes. $\Delta G$ is the average response from generations $2-6$. Results are presented \pm standard deviation of response. The standard error is the standard deviation divided by $24.5,18.7$ and 13.0 with 16,32 and 64 dams selected respectively.

\begin{tabular}{|c|c|c|c|c|c|c|}
\hline \multirow{3}{*}{$\begin{array}{l}\text { Generation } \\
\text { No }\end{array}$} & \multicolumn{6}{|c|}{ No of male sibships selected } \\
\hline & \multicolumn{3}{|c|}{ No of dams selected } & \multicolumn{3}{|c|}{$\begin{array}{c}8 \\
\text { No of dams selected }\end{array}$} \\
\hline & 16 & 32 & 64 & 16 & 32 & 64 \\
\hline 1 & $\begin{array}{r}0.199 \\
\pm 0.116\end{array}$ & $\begin{array}{r}0.220 \\
\pm 0.108\end{array}$ & $\begin{array}{r}0.251 \\
\pm 0.100\end{array}$ & $\begin{array}{r}0.172 \\
\pm 0.086\end{array}$ & $\begin{array}{r}0.201 \\
\pm 0.086\end{array}$ & $\begin{array}{r}0.247 \\
\pm 0.084\end{array}$ \\
\hline 2 & $\begin{array}{r}0.270 \\
\pm 0.134\end{array}$ & $\begin{array}{r}0.303 \\
\pm 0.122\end{array}$ & $\begin{array}{r}0.331 \\
\pm 0.114\end{array}$ & $\begin{array}{r}0.236 \\
\pm 0.102\end{array}$ & $\begin{array}{r}0.274 \\
\pm 0.093\end{array}$ & $\begin{array}{r}0.324 \\
\pm 0.085\end{array}$ \\
\hline 3 & $\begin{array}{r}0.265 \\
\pm 0.128\end{array}$ & $\begin{array}{r}0.317 \\
\pm 0.137\end{array}$ & $\begin{array}{r}0.342 \\
\pm 0.117\end{array}$ & $\begin{array}{r}0.243 \\
\pm 0.103\end{array}$ & $\begin{array}{r}0.282 \\
\pm 0.101\end{array}$ & $\begin{array}{r}0.328 \\
\pm 0.094\end{array}$ \\
\hline 4 & $\begin{array}{r}0.253 \\
\pm 0.129\end{array}$ & $\begin{array}{r}0.305 \\
\pm 0.119\end{array}$ & $\begin{array}{r}0.332 \\
\pm 0.117\end{array}$ & $\begin{array}{r}0.234 \\
\pm 0.105\end{array}$ & $\begin{array}{r}0.277 \\
\pm 0.097\end{array}$ & $\begin{array}{r}0.319 \\
\pm 0.097\end{array}$ \\
\hline 5 & $\begin{array}{r}0.236 \\
\pm 0.127\end{array}$ & $\begin{array}{r}0.290 \\
\pm 0.117\end{array}$ & $\begin{array}{r}0.309 \\
\pm 0.115\end{array}$ & $\begin{array}{r}0.225 \\
\pm 0.100\end{array}$ & $\begin{array}{r}0.270 \\
\pm 0.099\end{array}$ & $\begin{array}{r}0.306 \\
\pm 0.088\end{array}$ \\
\hline 6 & $\begin{array}{r}0.225 \\
\pm 0.124 \\
\end{array}$ & $\begin{array}{r}0.264 \\
\pm 0.116 \\
\end{array}$ & $\begin{array}{r}0.317 \\
\pm 0.112 \\
\end{array}$ & $\begin{array}{r}0.217 \\
\pm 0.098 \\
\end{array}$ & $\begin{array}{r}0.272 \\
\pm 0.092 \\
\end{array}$ & $\begin{array}{r}0.295 \\
\pm 0.090 \\
\end{array}$ \\
\hline$\Delta G$ & $\begin{array}{r}0.250 \\
\pm 0.061\end{array}$ & $\begin{array}{r}0.296 \\
\pm 0.055\end{array}$ & $\begin{array}{r}0.326 \\
\pm 0.055\end{array}$ & $\begin{array}{r}0.231 \\
\pm 0.048\end{array}$ & $\begin{array}{r}0.275 \\
\pm 0.046\end{array}$ & $\begin{array}{r}0.314 \\
\pm 0.043\end{array}$ \\
\hline
\end{tabular}

(in generation 3 instead of in generation 2) and the decline in response over time was less extreme.

Table $\mathrm{X}$ summarises the mean response and inbreeding rates achieved by the hierarchical and factorial sibship schomes. In addition, to disentangle the effects of the mating design and the use of full brothers, results of factorial (2 sires per dam) and hierarchical sibship (2 males used per selected sibship) schemes are also presented.

Response rates in factorial schemes were $2-13 \%$ higher than in hierarchical schemes. The use of 2 males per selected sibship with either mating design, in general, yiclded higher response rates (up to $9 \%$ ) when 4 sibships were selected and slightly lower response rates (up to $3 \%$ ) when 8 sibships were selected. The advantages of doubling the sire number ( $\mathrm{g}$ increasing the male selection intensities) outweighed the disadvantages (the loss of family information) when 4 sires were selected but not with 8 sires.

With 4 sires selected, inbreeding in the factorial and hierarchical schemes accumulated at a similar rate. With 8 sires selected, the restrictions imposed on sire family sizes by the hierarchical mating structure meant that inbreeding rates 
Table X. Rates of response and inbreeding averaged over generations two to six (inclusive) with hierarchical (H), hierarchical sibship (HS) (2 males per sibship), factorial (F) (2 sires per dam) and factorial sibship (FS) schemes (2 sires per dam and 2 males per sibship) ${ }^{1}$.

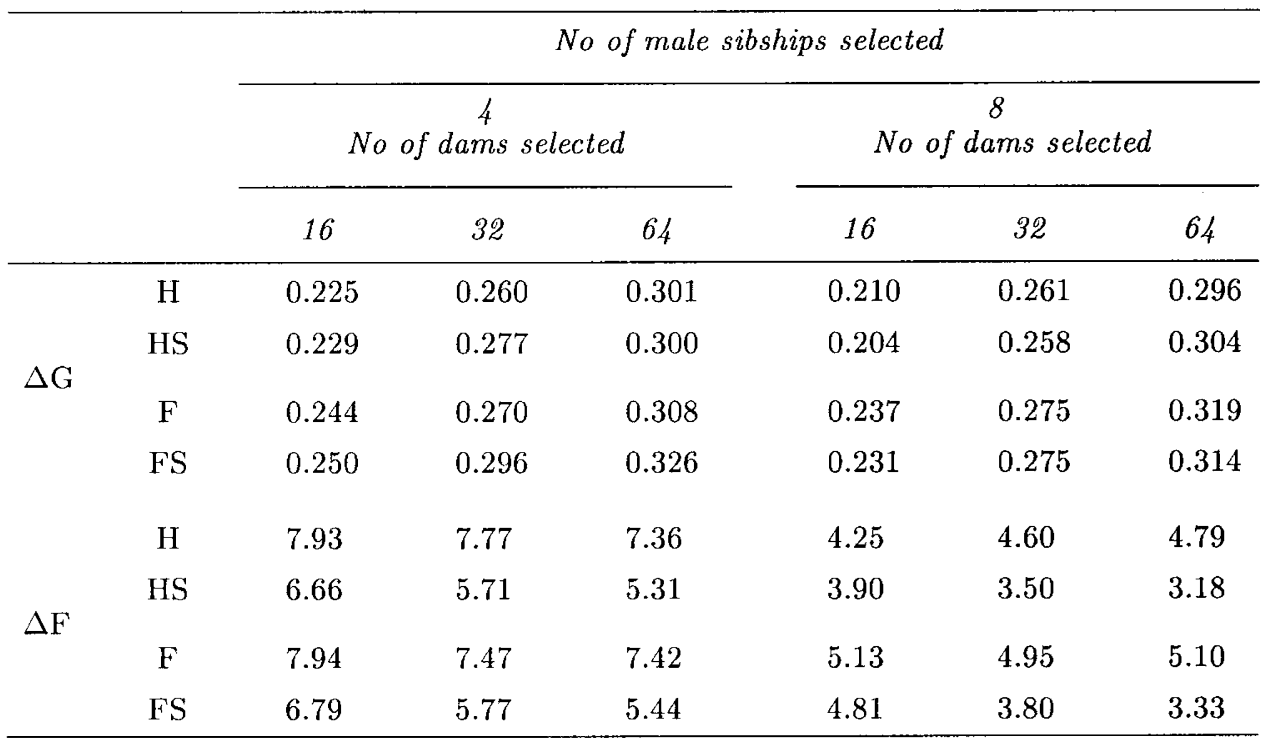

${ }^{1}$ Standard errors ranged from $0.002-0.005$ for response and from 0.03-0.10 for inbreeding.

in hierarchical schemes increased as more dams were selected and were lower than in factorial schemes. The use of 2 males instead of 1 from each selected sibship reduced inbreeding rates substantially (6-35\%), regardless of mating design.

\section{DISCUSSION}

The problem of inbreeding, caused by selecting small numbers of sires and dams from a finite pool of candidates using overlapping family information, is of utmost importance in MOET nucleus breeding programmes. For this reason any practical method of minimising the problem should be evaluated. Sibship schemes offer some possibilities here.

Unless embryo or semen sexing is available and in use, equal numbers of sons and daughters are expected on average from each dam. By allowing more than one male from each selected sibship to be used, inbreeding should be reduced without suffering a loss in selection pressure.

Simulation results showed this to be true. With 32 dams selected, inbreeding rates per generation were reduced by $24-34 \%$ with 2,3 or 4 males per sibship used. Similar reductions were found in juvenile MOET nucleus schemes by Toro and Silio (1989). The relationship between inbreeding rates and the number of brothers used was not linear. The reduction in inbreeding from using 2 males per sibship instead 
of 1 was far superior to using 4 males per sibship instead of 2 . Thus little effort is required to make substantial reductions in inbreeding. Results with 16 and 64 dams selected (table X) also demonstrated this point.

As a consequence of the balance between intensities and accuracies of selection, the effect of using more than 1 male per selected sibship on genetic response depended on the number of sibships selected and the number of males per sibship used. The effect on response was most favourable when few sibships were selected and when 2 males per sibship were used.

Woolliams (1989) predicted that factorial mating designs in MOET nucleus schemes, with 1 male used per selected sibship, could increase response without affecting inbreeding. His predictions were based on schemes with 4 sires and 36 dams. Simulation results presented here for 4 sires and 32 dams support his conclusions, despite the higher inbreeding rates and substantially lower rates of response found.

As the number of sires mated to each dam was increased from 1 to 4 , response to selection increased stepwise by up to $13 \%$. For these 4 schemes the rate of inbreeding was restricted to $7.5-7.8 \%$ per generation and was highest in the hierarchical scheme. Results with 8 sires and 32 dams suggest that the conclusions of Woolliams (1989) are not universal. In this case, the increase in response (up to $12 \%$ ) was accompanied by a corresponding increase in inbreeding (up to 14\%). Simulation studies have also demonstrated the advantages of factorial mating designs in juvenile MOET nucleus schemes (Toro and Silio, 1989).

The increased responses achieved with factorial mating designs were due to changes in male selection intensities. Because of this, the effect on response depends on the proportion of males selected. The additional responses achieved by using factorial instead of hierarchical designs should be greater in schemes with a high proportion of males selected (ie low selection intensities) than in schemes with a low proportion selected. Results in table X confirm this. Of the 6 schemes studied, the benefits of factorial mating were highest with 8 sires and 16 dams $(50 \%$ of males selected) and lowest with 4 sires and 64 dams (6\% of males selected).

In general, using male sibships was a successful strategy for reducing inbreeding while factorial mating designs were successful in increasing response. Factorial sibship schemes, which use both strategies, combined these 2 advantages. For the 6 breeding programmes examined, factorial sibship schemes yielded 5-14\% higher genetic gains and, with one exception, 14-30\% lower rates of inbreeding.

How do the MOET nucleus schemes described here, which are modifications of the original breeding plans of Nicholas and Smith (1983), compare with traditional progeny testing schemes? From table $\mathrm{X}$ we can see that if schemes with inbreeding rates exceeding $1 \%$ per annum are considered unacceptable, response rates of 0.76 , 1.03 and $1.18 \%$ of the mean (assuming a generation interval of $4 \mathrm{yr}$ and a coefficient of variation of $15 \%$ ) can be achieved annually with 16,32 or 64 dams. selected respectively ( $i e$ from schemes transferring $\approx 250,500$ or 1000 embryos annually).

These results are lower than theoretically possible in efficient progeny testing schemes. However, 2 important points must be taken into consideration. The first is that responses from MOET nucleus schemes can be greater than found here. This can be achieved in a number of ways; by increasing the nucleus size, by opening the nucleus to genetically superior stock or by employing overlapping instead of 
discrete generations of selection. The second is that, genetic progress aside, MOET nucleus schemes offer additional advantages over progeny testing schemes, such as the increased control possible over all aspects of selection and the recording of traits not normally included in dairy cattle selection programmes (Ruane, 1988).

Simulated responses were calculated assuming that the generation intervals were the same as in the hierarchical schemes. Of the breeding schemes outlined only the factorial schemes may violate this assumption, but in most situations it will make little difference. For example, if donors were flushed 3 times in the hierarchical scheme to generate families of 4 daughters and 1 son per dam, results show that factorial schemes could still achieve $10 \%$ higher rates of response without increasing the generation interval.

In hierarchical schemes, full brothers are not utilised and they serve no purpose because only 1 son per dam is eligible for selection. In this situation, any strategy which can use full brothers to reduce inbreeding and/or which can increase response by generating more male sibships of smaller size will be superior.

However, alternative options exist. Traits can be measured on males and within sibship selection practised. For example, it is currently possible to evaluate males for traits which may be economically important, such as growth rate, conformation or feed efficiency, while, in the future, reliable indicator traits of dairy performance may be available (Woolliams and Smith, 1988). The optimal scheme, which may involve some combination of within sibship selection with the use of factorial designs or sibship selection, will depend on the selection objectives and the traits recorded.

Another option, which should be possible with embryo sexing, is to reduce the size of the male sibships. By transferring fewer male embryos, resources can be freed for other uses. A possible disadvantage of this strategy is that by transferring fewer male embryos, male selection intensities may fall due to variation in family sizes and sex ratios (Ruane, 1991).

Throughout this study, schemes were compared using mean responses over generations 2-6. However, responses were not constant over time. Ruane and Thompson (1991) have discussed this in greater detail.

The initial base population was in linkage equilibrium. Because of the intense and accurate selection of nucleus founders, the between-family variances fell from 0.125 to $\approx 0.06$ and consequently the accuracies of selection of their offspring were quite low. For this reason, genetic gain achieved at generation one was considerably lower than in later generations. Genetic variance rose from $\approx 0.185$ to 0.2 at generations 2 and, in the absence of inbreeding, it changed very little in subsequent generations. This is in contrast with the observations of Wray and Hill (1989), who suggested that at least 6 generations of selection were needed before the variance stabilised.

As inbreeding accumulated, selection responses declined. Inevitably the decline was greater in schemes with higher inbreeding rates. Table V illustrates this clearly. With one male per sibship, the decline in response over generations 2-6 was far more substantial compared with using 4 males per sibship. As a consequence, there were some changes in the ranking of schemes over time. By comparison, for schemes with similar inbreeding rates, such as factorial schemes in table VII, rankings changed very little from generation to generation. The increased competitiveness of schemes with low inbreeding rates over time would be considerably greater if inbreeding depression was included in the model. 
To summarise, the time horizon used can affect the ranking of schemes. If the time horizon was extended, the ranking of schemes with larger effective population sizes would improve. In this study, 6 generations of nucleus selection were carried out because it was considered that the time required, $\approx 24 \mathrm{yr}$ from the selection of founder animals to the last round of selection within the nucleus, was realistic for a dairy cattle breeding programme.

Three alternative mating designs and selection strategies have been examined in this study. Other possibilities exist, although they seem to be of limited value. De Roo (1988) evaluated the importance of mating selected animals that were least related and showed that this could postpone but not prevent the accumulation of inbreeding in a closed nucleus herd of pigs. Ruane (1990) investigated the possible benefits of using assortative mating in adult MOET nucleus schemes with 16, 32 or 64 dams and 4 or 8 sires selected. Although response was increased by up to $5 \%$ in 5 of the 6 schemes, response was more variable and inbreeding rates were $10-50 \%$ higher compared with random mating.

The original proposals by Nicholas and Smith (1983) for the use of MOET in a closed dairy cattle herd were based on a hierarchical mating design with 1 male per sibship eligible for selection. This study has shown that substantial improvements can be achieved by altering the design of these schemes. Using more than 1 male from each selected sibship reduces the inbreeding rate while factorial mating designs increase the response to selection. Factorial sibship schemes, which combine both strategies, reduce inbreeding and increase response.

\section{ACKNOWLEDGMENTS}

Financial support of this study was provided by Premier Breeders and the Milk Marketing Board. I am grateful to R Thompson and B McGuirk for their help and advice and to $\mathrm{R}$ Johnston for typing the manuscript.

\section{REFERENCES}

Bulmer MG (1971) The effect of selection on genetic variability. Am Nat 105, 201211

Bulmer MG (1980) The Mathematical Theory of Quantitative Genetics. Clarendon Press, Oxford

Burrows PM (1972) Expected selection differentials for directional selection. Biometrics 28, 1091-1100

Cochran WG, Cox GM (1957) Experimental Designs. John Wiley and Sons, London, 2nd edn

Colleau JJ, Mocquot JC (1989) Using embryo transfer in cattle breeding. 5th Annual Meeting, Eur Embryo Transfer Assoc, Lyon, France

De Roo G (1988) Studies on breeding schemes in a closed pig population. $\mathrm{Ph} D$ Thesis, Agricultural University, Wageningen, The Netherlands

Falconer DS (1981) Introduction to Quantitative Genetics. Longman, London, 2nd edn

Hill WG (1976) Order statistics of correlated variables and implications in genetic selection programmes. Biometrics $32,889-902$ 
John JA, Wolock FW, David HA (1972) Cyclic Designs. Nat Bur Standards, Appl Math Ser 62

Nicholas FW, Smith C (1983) Increased rates of genetic change in dairy cattle by embryo transfer and splitting. Anim Prod 36, 341-353

Ruane J (1988) Review of the use of embryo transfer in the genetic improvement of dairy cattle. Anim Breed Abstr 56, 437-446

Ruane J (1990) Evaluation of genetic improvement programmes using multiple ovulation and embryo transfer in dairy cattle. $\mathrm{Ph} \mathrm{D}$ Thesis, University of Edinburgh Ruane J (1991) The importance of family sizes in adult multiple ovulation and embryo transfer (MOET) nucleus breeding schemes in dairy cattle. Anim Prod (in press)

Ruane J, Thompson R (1989) Simulation of an adult multiple ovulation and embryo transfer (MOET) nucleus breeding scheme in dairy cattle. In: New Selection Schemes in Cattle: Nucleus Programmes (Kalm E, Liboriussen T, eds) Pudoc, Wageningen, $72-80$

Ruane J, Thompson R (1991) Comparison of simulated and theoretical results in adult MOET nucleus schemes for dairy cattle. Livest Prod Sci (in press)

Schaeffer LR, Kennedy BW (1986) Computing strategies for solving mixed model equations. J Dairy Sci 69 , 575-579

Toro M, Silio L (1989) Genetic simulation of juvenile MOET breeding nucleus schemes in dairy cattle. In: New Selection Schemes in Cattle: Nucleus Programmes, (Kalm E, Liboriussen T) Pudoc, Wageningen, 64-71

Woolliams JA (1989) Modifications to MOET nucleus breeding schemes to improve rates of genetic progress and decrease rates of inbreeding in dairy cattle. Anim Prod $49,1-14$

Woolliams JA, Smith C (1988) The value of indicator traits in the genetic improvement of dairy cattle. Anim Prod 46, 333-345

Wray NR, Hill WG (1989) Asymptotic rates of response from index selection. Anim Prod 49, 217-227 